\title{
100 Years since the Birth of Milton Friedman
}

\section{Marek Loužek ${ }^{1}$}

\begin{abstract}
The paper deals with the economic theory of Milton Friedman. Its first part outlines the life of Milton Friedman. The second part examines his economic theories "Essays in Positive Economics" (1953), "Studies in the Quantity Theory of Money" (1956), "A Theory of the Consumption Function" (1957), "A Program for Monetary Stability" (1959), "A Monetary History of the United States 1897 to 1960" (1963), and "Price Theory" (1976). His Nobel Prize lecture and American Economic Association lecture in 1967 are discussed, too. The third part analyzes Friedman's methodology. Milton Friedman was the most influential economist of the second half of the 20th century. He is best known for his theoretical and empirical research, especially consumption analysis, monetary history and theory, and for his demonstration of the complexity of stabilization policy.
\end{abstract}

Key words: Chicago School of Economics, Milton Friedman, monetarism, quantitative theory of money, theory of consumption function

JEL Classification: B212, B31, E40, N10, 011

Milton Friedman was born one hundred years ago, which gives us an opportunity to commemorate this famous economist who has become a legend of economic theory indeed, and with his permanent income hypothesis, foundation of monetarism and the methodology of positive economics will forever be an inseparable part of economic theory. Why was Friedman's economics such a revolutionary one, and why can we still learn much from him?

Milton Friedman's work is vivid and encompasses a broad scale, from highly expert and technical essays, to popular articles published in Newsweek, and to politicalphilosophical books. Friedman himself was able to distinguish among various "genres", knowing when he was writing a popular book, and when he was working on a scientific article. He managed to master both of these spheres. This overview article does not want to deal with Friedman's political publications; it aims to outline his economic theory and methodology.

Its first part focuses on life of Milton Friedman. The second part analyzes his economic theory as it was developed in "Essays in Positive Economics" (1953), "Studies in the Quantity Theory of Money“ (1956), "A Theory of the Consumption Function" (1957), "A Program for Monetary Stability” (1959), "A Monetary History of the United States

${ }^{1}$ Doc. PhDr. Ing. Marek Loužek, Ph.D., Faculty of Economics, University of Economics, nám. W. Churchilla 4, 13000 Prague 3. 
1897 to $1960 "$ " (1963) and "Price Theory" (1976). The third part of this essay discusses Friedman's methodology.

\section{Friedman's Life}

Milton Friedman was born on July 31, 1912 in New York City (Schwarz in Holman, 1999). His parents had originally come from the Ukraine and while still children, they immigrated to the USA. Milton had three older sisters. Having graduated from Rahway High School in 1928, he enrolled bachelor programme studies at Rutgers University in Newark. The academic year 1932-33 found him at University of Chicago, and the following at Columbia University (Sojka 1996).

For 1934-35 he was back at University of Chicago, spending the year working as a research assistant for Professor H. Schultz. From 1935 to 1937 he worked for the National Resources Committee and participated in preparation works for a large consumer budget study. From 1937 to 1941 he assisted Simon Kuznets in National Bureau of Economic Research - a private scientific institution founded in 1920. He got married to Rose Director in 1938 (Friedman 1999).

In 1941-43 he worked for the US Department of the Treasury in the department of taxation research. From 1943 to 1945 he was back at Columbia University, this time as a part of a group of Harold Hotelling's and Allen Wallis' statisticians. For the academic year 1945 - 1946, he was appointed an associate professor of economics at University of Minnesota, and in 1946, Columbia University awarded him a PhD. for his dissertation (Friedman 1999).

In 1946, Friedman accepted an offer to teach at the Department of Economics of University of Chicago, where he was appointed an associate professor. In 1948, he became a Professor. In 1951, his seminar on money and banking is operational. Friedman was not only a professor at University of Chicago - alongside with his professorial chair, he engaged himself in the National Bureau of Economic Research. In the academic year 1953-54, he was employed as a visiting professor at Cambridge University in Great Britain (Ebenstein 1997).

It was from the 1950s to the 1970s that Friedman published his most famous scientific works: "Essays in Positive Economics" (1953), "A Theory of the Consumption Function" (1957), and "A Monetary History of the United States 1897 to 1960" (1963). Besides these, he also published many popular articles and books which were sold by millions. In 1976 Friedman won the Nobel Memorial Prize in Economics for his achievements in the fields of consumption analysis, monetary history and theory, and for his research in the field of stabilisation policy.

Until 1977, Friedman was a lecturer at University of Chicago, subsequently cooperating with the university in the field of science and research, and eventually becoming a senior fellow of the Hoover Institution at Stanford University. Milton Friedman published his articles and essays in the 1990s, too, and was a sought-after participant of not only scientific conferences, but political and medial events, too. His theories were used by the New Right and supporters of classical Liberalism. Milton Friedman died on November 16, 2006. 


\section{Economic Theories}

It is not easy task to analyze Friedman's theoretical work for the author touched an incredible range of topics. While still fairly young, Friedman published "Essays in Positive Economics" (1953) which was followed by "Studies in the Quantity Theory of Money" (1956), "A Theory of Consumption Function" (1957), "A Program for Monetary Stability" (1959), "A Monetary History of the United States" (1963), and "Price Theory" (1976).

Still shortly after the WWII, Friedman and Simon Kuznets (1945) published a statistical and technical study of budgets of the so called "independent professionals", where they analyzed impact of restrictions present while entering the sector (medical professions), which increases income of members of a privileged group in comparison to others. The study conclusions look absolutely obvious to us, however, in the time of its publication, the study provoked great hostilities among doctors.

\section{1. "Essays in Positive Economics" (1953)}

The first Friedman's book by which he drew attention to himself was "Essays in Positive Economics" (1953), which is not a compact and systematic monograph but a collection of articles that Friedman published mainly in American journals specialized in economics in the 1940s and at the beginning of the 1950s, the most well-known of them being the methodology of positive economics, which shall be analyzed in the part of this essay that deals with methodology.

In his article "The Marshallian Demand Curve" (1949), Friedman reproves Marshall (who was a neoclassical economist and so Friedman read him carefully and preferred him to Walras and the theory of general equilibrium) for not defining exactly in his "Principles of Economics" the demand curve as a function of certain variables, and settling for an intuitive interpretation of the demand curve as a dependence between volume of commodity and price.

Common understanding of Marshall's demand curve includes a ceteris paribus clause related to consumer preferences, monetary income and a price of another commodity. Friedman claims that it is more faithful to the letter and spirit of Marshall's writing to expect ceteris paribus to be related to preferences, not to real income and prices of commodities that are closely related to the original commodity (every closely related commodity).

Young Friedman accuses Marshall of a discrepancy within his Principles, claiming that Marshall was so strongly influenced by common understanding of the problem that he did not even recognize the inconsistency in his early work. Friedman then explains the differences between both conceptions exactly and graphically, and stresses that the latter one is better.

"The alternative interpretation of the demand curve not only is faithful to both the letter and the spirit of Marshall's work, but is also more useful for the analysis of specific problems than is the demand curve commonly employed. The acceptance of a less useful definition seems to me to be a consequence of a changed conception of the role of theory in economic analysis. The current interpretation of the demand curve is Walrasian; and so is current economic theory in general" (Friedman 1953: 93). 
In his article "Welfare Effects of Income Tax and Excise Tax" (1952), Friedman rebuts the proof acknowledged by Hicks, young Stigler and others, that income tax is a more effective kind of tax as it is global and does not produce substitution effects such as excise duty imposed on a specific commodity. He was not after rebutting the opinion as such; rather than that, he tried to rebut the illegitimate logical reasoning it claimed.

The traditional proof is - according to Friedman - based on a false assumption that what is valid for individuals is valid for a community as a whole, too. "If prices did not fall relative to money income, the most significant implication of either the excise tax or the income tax would be the same, namely, that other tended to produce unemployment and a reduction in the alternatives available to consumers. Therefore, both taxes affect the 'wealth' in the same way, and the difference between them is a rather second-rate one" (Friedman 1953: 105-106).

Friedman's article “The Effects of a Full-Employment Policy on Economic Stability. A Formal Analysis" (1951) surprised the community of economists by its quiescent and elegant analysis which, using formal statistics, shows high probability of ineffectiveness of otherwise well-intended stabilisation policies.

The author examines stochastically the equation $\mathrm{Z}(\mathrm{t})=\mathrm{X}(\mathrm{t})+\mathrm{Y}(\mathrm{t})$, where $\mathrm{X}(\mathrm{t})$ is income in time $\mathrm{t}$ without stabilisation policies, $\mathrm{Y}(\mathrm{t})$ is the effect of stabilisation policies, and $\mathrm{Z}(\mathrm{t})$ is the total income in time $\mathrm{t}$. According to the statistical theorem, the variance is $\sigma \mathrm{Z} 2=\sigma \mathrm{X} 2+\sigma \mathrm{Y} 2+2 . \mathrm{rXY} . \sigma \mathrm{X} . \sigma \mathrm{Y}$. Should the stabilization policies be perfectly effective, their effect should be directed reversely, in the direction towards the deviation from the average $\mathrm{X}$. In such case, the $\mathrm{X}$ would perfectly negatively correlate with $\mathrm{Y}$ and rXY would be -1 . Ultimately perverse policies would, on the other hand, mean $\mathrm{rXY}=+1$.

In order for the stabilisation policies not to act in a destabilizing way, the correlation coefficient rXY would have to be in the interval $(-1 ;-0.5)$, which - as Friedman believed - is not very likely. Timing of the correct stabilization policies is the key, since any well-intentioned stabilization policy which comes too soon or too late yields destabilization effects. If the correlation coefficient is higher than -0.5 , economic policy is harmless rather than profitable.

"Good intentions, however admirable, are not enough. They will be abortive unless matched by the capacity to put them into effect... There has been little realistic examination of the inevitable limitations to the effectiveness of countercyclical action. There has been almost no recognition that vigorous countercyclical action may result in more instability than milder action. In this field, as in all other, the 'will' is too often mistaken for the 'deed"” (Friedman 1953: 132).

The article called "The Case for Flexible Exchange Rates" (1953) is a carefully structured argumentation in favour of flexible exchange rates. First of all, Friedman pays attention to alternative methods of international payments adaptations - 1) changes of exchange rates; 2) changes in domestic prices or income; 3) direct control; and 4) use of monetary reserves - and compares advantages and disadvantages of individual alternatives. The author confutes such bias against flexible exchange rates that they increase insecurity, instability and instigate speculations. It is proved that as regards timely adjustment of international payment, they are much faster and more effective, too. 
Friedman considered accumulation of foreign exchange reserves impractical, as demands on the reserves would be astronomical, indeed. Friedman thought that adaptation by the means of domestic prices and income would be too costly due to institutions and price rigidities. To Friedman, direct controls are the worst option of all; in his view, the simplest and the most elegant solution is in allowing rates to free-float and equalize supply and demand on the foreign exchange market. "The main goal of politics should not be to prevent such changes to happen, but to develop an effective system of adaptation, take advantage of their potential and minimize their disturbing effects" (Friedman 1953: 202).

The article called "A Monetary and Fiscal Framework for Economic Stability" (1948) is the first outline of Friedman's theory of "stability rule". Friedman claimed that economists of the 19th and early 20th centuries focused too much on the issue of resource allocation, and to a lesser degree dealt with the problematics of economic growth and short-term periodical fluctuations. The situation was inverted after the Great Depression of the 1930s, and economists became obsessed with short-term economic fluctuations and were trying to stabilize them, omitting long-term trends and effects completely.

While creating his framework for monetary and budget stability, Friedman proceeds from long-term goals. His proposal from 1948 is based on four points: 1) reform of monetary and banking system aiming to eliminate private money creation and discretion of central banks regarding the control of money supply; 2) definition of governmental costs connected with property and services based solely on the basis of a community and willingness to pay for public services; 3) programme of transfer payments and definition of conditions under which state aid shall be provided; 4) a progressive system of taxation based primarily on personal direct tax (Friedman 1953: 135-137).

Ideally, government should not provide the public with securities yielding interests and the Federal Reserve System would not operate on the free market. Deficit or surplus of the national budget would be reflected in the change of money offer, and the money offer would be changed by these fluctuations only. The higher the national income, the more budget receipts and lower volume of necessary transfers, which generates budget surplus which would be withdrawn from circulation by the central bank. The lower the national income then, the lower degree of revenue collection and greater degree of necessary transfers. The budget deficit which stems from that would require monetization and increase of the volume of money in circulation. According to Friedman, this strict and fairly simple policy should bring greater stability than any discretionary fiscal or monetary interventions.

\section{2. "Studies in the Quantity Theory of Money" (1956)}

In "Studies in the Quantity Theory of Money", which was written as a collection of essays of students participating in the Chicago workshop for money and banking in 1954, Friedman acknowledged the oral tradition of Chicago school prevalent in the 1930s (Friedman 1956). Rather than as a clearly defined theory, Friedman understands the quantity theory as an approach and an alternative to the Keynesian income-expense approach. In his opinion, University of Chicago managed to maintain the traditions of the quantity theory better than any other university after the Great Depression. 
"The Quantity Theory of Money. A Restatement" became classics. Friedman (1956: 321) rediscovers the M.V = P.Q equation, and takes it that as the demand for money is stable, the idea about increase of prices as a consequence of monetary expansion is still legitimate. Friedman does not rule out short-time deviations, although he claims that an increase in money supply in long-term horizon will result in an increase of prices.

James Tobin (1970), who tried to carry out a synthesis of Keynesian and neo-classicist models, opposed Friedman. Unlike Friedman, he did not expect money to circulate in constant speed, and offered his portfolio theory. Tobin's analysis questions Friedman's theory of effectiveness of monetary changes. From the analytical point of view, Tobin's theory is interesting indeed, however, empirical findings have not verified it completely.

Don Patinkin $(1969,1981)$ reacted to Friedman's resurrection of the quantity theory and argued against Friedman in two aspects: in monetary-demand approach as a means of restoration of the quantity theory, and his interpretation of the Chicago oral tradition. Patinkin reasoned that by stressing portfolio structure and degree of yields, Friedman's approach was a kind of upgrade of the Keynesian liquidity preference theory rather than being a quantity theory as such (Leeson 2000).

However, Patinkin did not find any predecessors of this approach in the Chicago tradition. In his opinion, the Chicago school did not understand the quantity theory as a theory of demand for money but as a theory relating the volume of money to aggregate demand like Fisher's equation. In Patinkin's view, Friedman uses the approach of money balances adopted in Cambridge. Economists in Chicago saw the speed of money returns as an unstable variable or quantity which is subject to dramatic changes, thus not being virtually uncontrollable.

George Tavlas (1997) distinguishes between two Chicago traditions: until 1936 and later. Before Keynes' "General Theory" was published, the Chicago tradition had been characterized by four aspects: 1) use of Fisher's quantity theory; 2) belief that changes in the speed of money circulation can be cumulative and may induce economic fluctuations; 3) conviction that problems of the financial sector sometimes deepen economic fluctuations; and finally, 4) defence of anti-cyclical changes in money supply carried out via deficits and state budget deficits with long-term balance. Tavlas concludes that the early Chicago tradition is very close to proposals concerning securing monetary and fiscal stability that Friedman came up with later.

Hammond (1999) emphasises three key motives of Friedman's reformulation of the quantity theory: his work at the National Bureau of Economic Research, traditional susceptibility towards Marshallian methodology, and the theory of value and use of the Cambridge approach of money balance. "All these moments clearly and distinguishably stand apart from the intellectual tradition ruled by the Keynesian income-expense theory" (Hammond 1999: 465).

Friedman was an economist who resurrected the neo-classical monetary theory and stressed the fact that monetary factors have an important influence on inflation. His view that 'money matters' was eventually accepted by the general economic community. Buttler expressed it in the following words: "When a person places the orthodox position in jeopardy, the first natural reaction is ignoration: the less it is spoken about, the better. When this person suddenly gains a few supporters, the second reaction is to 
taunt him, label him as an extremist. This phase is, nonetheless, followed by yet another one: others wittingly or unwittingly accept his views, but in order for him not to be too proud and influential, they mock him, saying: He is naive and claims that 'money matters' only. Everybody knows that money matters, but..." (Buttler 1985: 3).

\section{3. "A Theory of the Consumption Function" (1957)}

"A Theory of the Consumption Function" (1957) based on Friedman's early research is a comprehensive and methodological work of the young economist. The author proceeds from Dorothy Brady's and Margaret Reid's empirical findings about consumer behaviour of American households, and transforms them into a theoretical and formalized form. The central idea of the book is the fact that consumption of households does not react to fluctuations of actual income as supposed by Keynes, but is a consequence of the so called permanent income yp. The permanent income is a continuous income which existed in the past and most likely will occur in the future, too.

"Our analysis accordingly distinguishes sharply between income as recorded - which we term measured income - and the income to which consumers adapt their behaviour which we term permanent income, and similarly, between measured consumption and permanent consumption. Permanent income cannot be observed directly, it must be inferred from the behaviour of consumer units" (Friedman 1957: 221).

The hypothesis of the permanent income is stated in the following three equations (Friedman 1957: 26):

$$
\begin{aligned}
& \mathrm{cp}=\mathrm{k}(\mathrm{i}, \mathrm{w}, \mathrm{u}) \cdot \mathrm{yp}, \\
& \mathrm{c}=\mathrm{cp}+\mathrm{ct}, \\
& \mathrm{y}=\mathrm{yp}+\mathrm{yt} .
\end{aligned}
$$

The equation (2) is purely definitional (a sum of the permanent consumption and the transitory component of consumption); the same can be said about the equation (3) which is a sum of permanent income and transitory component of income. Equation (1) is the one that has substantial contents: the permanent consumption comes out of permanent income (which depends on interest rate, wealth and employment). Friedman supposes the mean value of the transitory component of both income and consumption to be zero. This is a conventional statistical assumption. Friedman transforms the equations (2) and (3) into a logarithmical form, where empirical results are better than in its arithmetical alternative (Chao 2003).

Using an econometrical method, Friedman examines these equations in various periods in time and according to American and international statistics, and eventually concludes that the hypothesis of permanent income gives better results than alternative hypotheses (the Keynesian ones in particular). In his opinion, $18 \%$ of the variance of the measured income in the USA and $13 \%$ of the measured income in Great Britain can be assigned to the transitory component. What remains is the permanent component (Friedman 1957: 56-57). 
Friedman does not find any proof of declining trend towards consumption with increasing income, as was predicted by Keynes. He arrives to the conclusion that the coefficient $\mathrm{k}$, i.e. rate of the permanent consumption and permanent income, is higher for salary recipients (0.9-0.95) than for groups of entrepreneurs $(0.8-0.9)$, which is in accord with the Keynesian ideas (Friedman 1957: 227).

Friedman's hypothesis of permanent income influenced the way economists look at consumer function, as from it stems the fact that consumption is much more stable than had been expected. As the transaction demand for money depends on consumer expenditures, which on the other hand depend on permanent income (and not actual income), the demand for money is rather stable (Schwarz in Holman 1999: 432-433).

\section{4. "A Program for Monetary Stability" (1959)}

The book called "A Program for Monetary Stability" (1959) is a compilation of lectures which Friedman held at the Fordham University in October 1959. To a great degree, Friedman elaborates his outlines of the "firm rule" for the monetary realm. He analyzes four basic problems: the background of monetary policy; instruments of Federal Reserve System, debt management and bank reform, and goals and criteria of monetary policy.

The initial question asked by the classical liberal Friedman deals with whether state should interfere in monetary and banking issues at all. Friedman responds by saying that stable currency must retain its value. Therefore, an effective external restriction must be applied on it. In order for it to work properly and correctly, its value must be kept on a level that is higher than marginal costs on its creation (free competition would otherwise result in a constant increase of volume of money, and thus in inflation).

The only way how to prevent this from happening is in a monopoly of state in creation and emission of money. "It is these features of money that justify interference of a government... A kind of moderately stable monetary framework seems to be an essential condition for effective function of private market economy. However, it is questionable whether the market itself would be able to provide such a framework. The basic function of a government is thus to provide and secure stable monetary order" (Friedman 1959: 8).

The fact that economic instability in the USA springs from monetary instability is the key idea of the Friedman's book. Its author looks at the recession in the 1830s and the 1840 s, the deceleration in 1873-79, the recession in the mid-1890s and contraction that occurred in 1907-08, and manages to identify monetary reasons that stood behind all those cases. Monetary instability arises from direct interference of the government, or from never-ending discussions regarding what should the monetary policy look like.

The author sees the solution of these problems in creation of stable monetary organization, in which it would be impossible to interfere ad hoc. "The primary problem dwells not in creating highly sensitive instruments which would be able to continuously adjust instability caused by different factors; it is in preventing occurrence of such a monetary organization which would itself be the source of the instability" (Friedman 1959: 23). 
When it comes to instruments of monetary policy, Friedman proposes to leave out required reserve and discount credits. However, unlike in his article written in 1948, now he considers operations in free market as an instrument of monetary policy which regulates the volume of money in circulation. "The proposed reforms would consolidate the relation between behaviour of the Federal Reserve System and changes in money supply, making it more direct and more predictable, and would eliminate external influences affecting money supply" (Friedman 1959: 51).

Friedman proposes to fix the growth of money supply to $4 \%$ per year, wants to forbid the Department of the Treasury to sell and purchase securities in the free market. The government would make up a potential deficit by drawing directly from the central bank, the surplus would be returned to the central bank (in fact, the debt proceedings would thus be in a single authority). Required minimum reserve would be set to $100 \%$, so that potential changes in money supply, which could not be influenced, would be eliminated completely.

\section{5. “A Monetary History of the United States 1897 to 1960" (1963)}

The monumental “A Monetary History of the United States 1897 to 1960" (1963) which Friedman published with Anna Schwartz, is the most influential of Friedman's scientific monographs. So whilst "Free to choose" or "Capitalism and Freedom" made Friedman famous all over the world and were sold by millions, only 20,000 copies of "A Monetary History of the United States" have been sold so far. Friedman addressed this pretty clearly in an interview from 1999: "If I had not done the more scientific, serious work, I would not have qualified for the lighter stuff... I would not have understood problems and would not be able to write the same things if I had not had the background provided by the scientific work" (quotation in: Robinson 1999: 18).

By examining time series, Friedman in his "A Monetary History of the United States 1897 to 1960 " finds out, that 1 ) the change in volume of money is closely connected to the degree of changes in nominal income, real income and prices; 2) interest rates are important for defining how much money people wish to keep, and the total volume of money in circulation, however, they have absolutely no relation to prices, income or product; 3 ) fluctuations in velocity of money supply are small in time.

Correlation coefficients between fluctuation of money supply and nominal income were estimated by Friedman to be 0.92 for the period of $1877-1914,0.79$ for 1920-1954 (deformations caused by the Great Depression), and 0.81 for the period of 1877-1954. Long-term relation between volume of money and real income were not ascertained, though. The maximum of the money supply growth overtakes the peak of economic growth by 18 months, while the relevant minimum in the money supply growth precedes the trough of the recession by approximately twelve months. Time lags oscillate between 13 and 24 months during conjuncture, 13 to 24 in recession.

Friedman did not leave out the hypothesis of permanent income in this book, either. The authors find out that measured income in expansion rises more robustly than permanent income. In relation to permanent income, the money supply climbs over-proportionately; in relation to measured income, the rise is below proportion. Income velocity of money shows slightly decreasing tendency, nonetheless, it started to climb after the WWII 
again. Friedman explains this deviation with the aforementioned expectations of stability among economic subjects.

Money supply is seen as an autonomous quantity which influences others. It defines various types of money aggregates: M1 = currency + demand deposits; M2 = M1 + time deposits. According to Friedman's measurements, the greatest dependency of money on monetary aggregates can be seen with M2. In his opinion, money is the key asset, definition of which is to a large extent arbitrary, yet it is immensely important for healthy operation of an economy.

Besides money, Friedman analyzes other assets, too: bonds, stocks, material goods and human capital. Although his function of demand for money is structurally richer, Friedman supposes and reasons by the means of empiricism as well, that demand for money is relatively stable. Keynes' division of demand for money into transactional and speculative was not used by Friedman.

Milton Friedman and Anna Schwartz explained the Great Depression by monetary factors, too. Diverting from the opinion of majority in saying that the crisis broke out in the banking sector, and is a proof of instability and fragility of market economy, both authors point out the fact that from 1929 to 1933, volume of money dropped by a third, and the restrictive politics of American central bank is to blame.

So while those who promote Keynes and his teaching saw the causes of economic depressions as coming from within - rooted in the market system itself, always threatening to erupt at any time and bring about another depression, Friedman saw the causes of a depression as an issue coming from without (Schwarz in Holman 1999: 438440). It was the erroneous monetary policy of central bank what made the common periodic recession (which would have most likely worn off in a short time) turn into a deep crisis lasting a whole decade.

In 1982, Friedman and Schwartz published an innovated version of the book, which they called "Monetary Trends in the United States and the United Kingdom" (1982). Here, the authors continue empirically testing the relationship between money supply and nominal income, choosing USA and Great Britain for they consider these two countries similar when it comes to functioning of monetary phenomena. They find out from 1870 to 1970 , volume of money grew faster than income in the USA; in Great Britain, the growth was not so prominent.

\section{6. "Price Theory" (1976)}

Friedman dusted off the price theory in his book "Price Theory" (1976), where he mathematically elaborated it, too. A great deal of the book focuses on evaluation of final products, the rest deals with the theory of distribution, which Friedman considers to be a particular case of price theory related to production factors. Principles which explain prices on goods and services markets explain prices on production factors markets, too.

According to Friedman, economics is a science about how a society deals with its economic problems. An economic problem is present at any place where rare sources are depleted in order to satisfy alternative goals. If resources are not rare, than there is no problem at all: there is nirvana. If resources are rare but only one goal exists, the problem related to their depletion is purely technological. 
"Economics is a social science, and therefore it primarily deals with those economic problems, solutions of which include cooperation and interaction of various individuals... Formally, an economic problem is the same for the economics of Robinson Crusoe, underdeveloped agricultural economics, modern industrial society based on a communistic organisation, and modern industrial society based on capitalistic organisation, too. In order to deal with their economic problems, these various societies take advantage of various institutional arrangements" (Friedman 1976: 2).

Friedman includes theory of demand, analysis of utility under uncertainty, relation between offer and cost curves and derived demand into "Price Theory", too. However, he focuses on the theory of distribution, marginal productivity, factors of production offer, wage and unemployment determination, relation between functional and personal division, and theory of capital and interest. He elaborates a typical neo-classical analysis using a mathematical apparatus of utility maximization during budget constraint and graphs.

Friedman claims that just as any other theory, an economic theory, too, can be meant in two ways - as a language or an analytical system, or as a set of substantive and empirical propositions. With respect to theory understood in the former meaning, its usability and not veracity or falsity is the relevant question that must be dealt with. Economic theory as a set of substantive proposition includes statements that in principle are possible to test for they attempt to predict.

"The definition of demand curve is a 'theory as a language'. Nonetheless, the statement that the demand curve bends down and towards the right side is a theory as a substantive empirical proposition. It has got empirically observable consequences, while the definition of the demand curve does not. The theory as a language corresponds to what Marshall calls the analysis instruments. Its goal is to create a language which shall be more fruitful both when it comes to clarification of ideas, and research of substantive propositions" (Friedman 1976: 8).

\subsection{The 1967 Meeting of American Economic Association and the Nobel Prize lecture}

One of Friedman's most famous appearances occurred in December 1967 at the annual meeting of American Economic Association (AEA). Friedman criticised Phillips curve, arguing that trade off relation between unemployment and inflation, which became the cornerstone of the neo-classical synthesis of the 1950s, is valid only in short-term period (Friedman 1968). According to Friedman, unemployment cannot deviate from its natural rate in the long run. 


\section{Graph 1. Phillips curve according to Friedman}

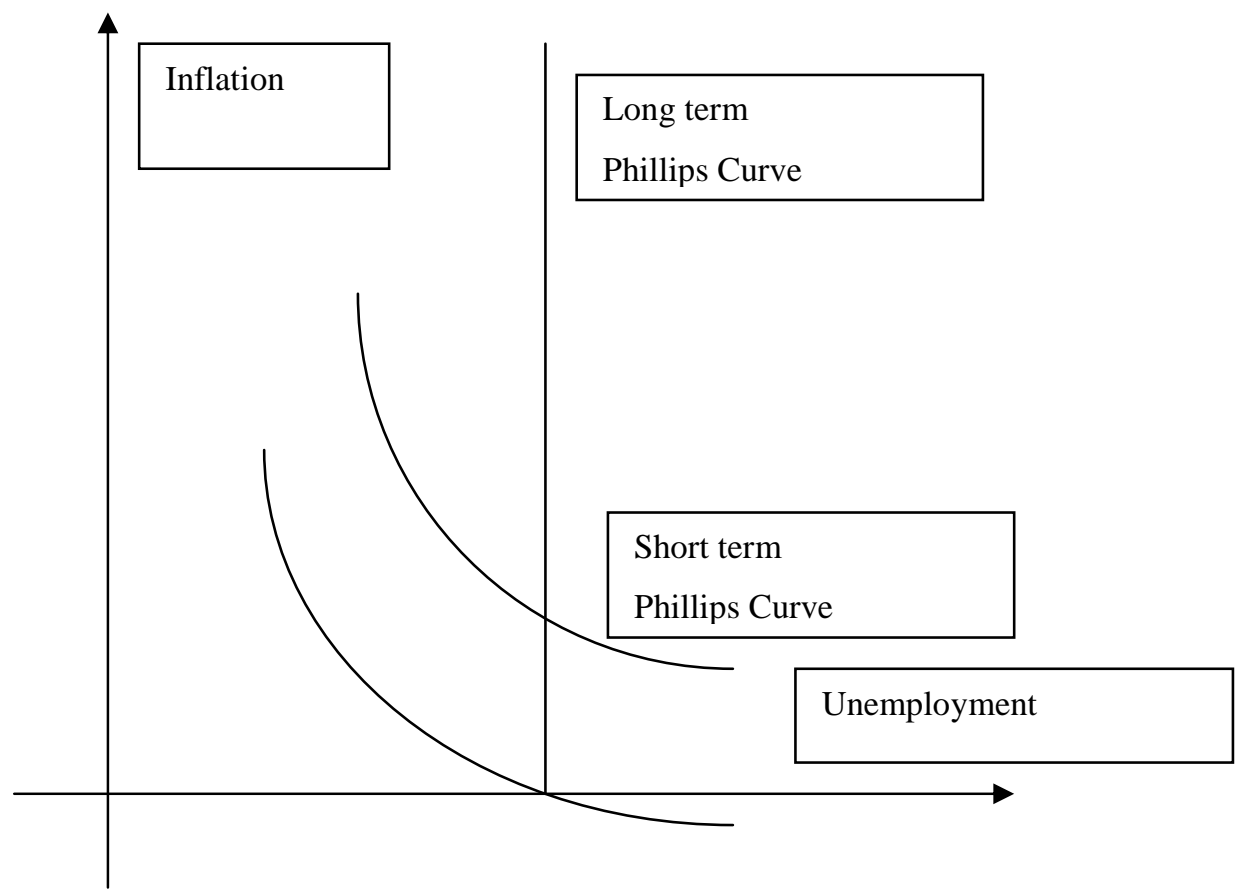

Friedman claimed that the Phillips curve, which was drawn as a graph of inverse proportion by advocates of the neo-Keynesian theory in the $1950 \mathrm{~s}$, is vertical in the long run (see graph 1). In his Nobel Memorial lecture "Unemployment and Inflation" (1975) which Friedman gave on December 13, 1976 after being awarded the Nobel Memorial Prize for Economic Science, he expressed a provocative hypothesis that the Phillips curve can climb in case of fluctuating economic policy. He substantiated it with the socalled stagflation, i.e. concurrent increase of unemployment and inflation occurring in the 1970s.

Friedman says that in today's world, many countries are characterized by socially destructive inflation, abnormally high unemployment or by wasting resources not because their values are different, but because the views on consequences of various state interventions are wrong. These demerits can be - at least in principle - set right by progress in economic science. Friedman shows on the example of the Phillips curve how shifts of opinions and views among scientists are to a great extent based on pragmatic and sober arguments, not ideological references.

"Government policy about inflation and unemployment has been at the centre of political controversy. Ideological war has raged over these matters. Yet the drastic change that has occurred in economic theory has not been a result of ideological warfare. It has not resulted from divergent political beliefs or aims. It has responded almost entirely to the force of events: brute experience proved far more potent than the strongest of political or ideological preferences" (Milton Friedman: Nobel Memorial Lecture, December 13, 1976 www.nobelprize.org). 
Thanks to his work dealing with politics, Friedman became famous not only in economic circles, but in the widest public, too. He got invitations to numerous television debates to assess economic measures taken by the President or election candidates, his economic-political suggestions and proposals were embraced and heard carefully by the American President Ronald Reagan and the British Prime Minister Margaret Thatcher (Friedman 1992). For that reason were the 1970s and the 1980s the era of privatization, liberalisation and tax cuts.

\section{Methodology}

Milton Friedman's methodology was a breakthrough, too, as it blessed the practice of mainstream economists. Friedman elaborated his methodology in a few articles, the most famous being the essay "The Methodology of Positive Economics" which is a part of "Essays in Positive Economics" (1953). Here Friedman formulated his views of positive economics and picked up the threads of the methodological tradition of value neutrality in social sciences.

\section{1. "The Methodology of Positive Economics" (1953)}

The essay "The Methodology of Positive Economics" (1953) deals with three topics: 1) difference between positive and normative economics; 2) the character of positive economics; and 3) the question where a hypothesis can be tested by unrealistic nature of its assumptions. In the introduction, Friedman quotes the methodologist classic, J. N. Keynes, and his "The Scope and Method of Political Economy" (1896).

According to Friedman, the problem of differentiation of positive and normative economics is natural: conclusions of economics are important for normative questions. People are usually happy if certain positive findings 'match' their normative convictions, and are distempered when positive facts do not correspond to them.

Positive science means development of predictions, their correctness, scope and unity with experience. Economics can be a disinterested science, just as any other physical sciences. The fact that researchers are a part of the subject examined more than they are in physics creates certain problems related to reaching objectivity, however, these are not problems impossible to get round. Moreover, they do not substitute the fundamental difference between social and natural sciences.

Of course, normative economics dealing with what should be is by no means independent on positive economics dealing with what is. Any economic-political conclusion is grounded on prediction of consequences brought about (or not) by particular measures. In Friedman's opinion, the main discrepancies related to economic politics stem from unawareness of positive facts, not ideological convictions.

"I venture the judgment that currently in the Western world, and especially in the United States, differences about economic policy among disinterested citizens derive predominantly from different predictions about economic consequences of taking action - differences that in principle can be eliminated by the progress of positive economics rather than from fundamental differences in basic values, differences about which men can ultimately only fight" (Friedman 1953: 5). 
Friedman mentions legislation of minimum wage as an example. Its proponents believe that the provision of minimum wage shall lower poverty by increasing wages of people whose wages are below the minimum wage. On the other hand, objectors of the minimum wage are convinced that the measures shall result in greater poverty, as increase of unemployment shall occur. The debate on whether it is suitable to introduce the institution of minimum wage is primarily a question of positive knowledge; the question of normativeness is only secondary.

"If this judgment is valid, it means that a consensus on 'correct' economic policy depends much less on the progress of normative economics proper than, on the progress of a positive economics yielding conclusions that are, and deserve to be, widely accepted. It means also that a major reason for distinguishing positive economics sharply from normative economics is precisely the contribution that can thereby be made to agreement about policy" (Friedman 1953: 6-7).

Friedman sees the main task of positive science in development of 'theories' or "hypotheses which purvey valuable and meaningful predictions about phenomena which have not been seen yet. Theory as a language is a set of tautologies, a filler system for organisation of empirical material. "Economic theory must be more than a structure of tautologies if it is to be able to predict and not merely describe the consequences of action; if it is to be something different from disguised mathematics" (Friedman 1953: 11-12).

As a set of hypotheses, a theory should be judged according to its ability to predict classes of phenomena it wishes to explain. In Friedman's view, the only relevant test of hypothesis validity comprises of a comparison of prediction with experience. Factual evidence can never 'prove' a hypothesis, though it can offer an empirical 'sieve' which shall let the theory through or not. In case a sufficient number of tests is let through, than it is considered a credible theory. Predictions which test a hypothesis can concern and include phenomena occurring in past, presence and future, too.

In Friedman's view, there is a definite number of observed facts; the number of hypotheses is infinite, though. The choice of alternative hypotheses is therefore arbitrary to some extent, and aspects of 'simplicity' and 'fruitfulness' are what motivates it most often. Weeding out unsuccessful hypotheses is slow and difficult, for they are scarcely rebutted definitely, and do reappear disguised as something else time and time again. There is a problem of experiments in social sciences, however, it does not stipulate a fundamental difference between social and natural sciences.

The approach that Friedman opposes is that hypotheses not only have implications, but assumptions, too, and that the assumptions being in concordance with reality testify validity of a hypothesis which is different or additional to the test carried out through implications. The ratio between the meaning of a theory and 'realism' of its assumptions is exactly reverse.

“Truly important and significant hypotheses will be found to have 'assumptions' that are wildly inaccurate descriptive representations of reality, and, in general, the most significant the theory, the more unrealistic the assumptions... A hypothesis is important if it 'explains' much by little... To be important, therefore, a hypothesis must be descriptively false in its assumptions" (Friedman 1953: 14). 
The question which must be asked in relation to theory assumptions is not whether they are realistic; they never are, but whether they are a good approximation for the purpose given. Two tests which were originally intended to be independent have narrowed to a single one. Friedman uses theory of imperfect competition, which tried to substitute the neo-classical paradigm of imperfect competition, as an example of erroneous thinking about assumptions.

"The lengthy discussion on marginal analysis in the American Economic Review some years ago is an even clearer, though much less important, example. The articles on both sides of the controversy largely neglect what seems to me clearly the main issue - the conformity to experience of the implications of, the marginal of, the marginal analysis and concentrate on the largely irrelevant question whether businessmen do or do not in fact reach their decisions by consulting schedules, or curves, or multivariable functions showing marginal cost and marginal revenue" (Friedman 1953: 15).

In order to convince his readers of correctness of his thesis on unrealistic assumptions, Friedman mentions an example from the realm of physics: formula of free-fall in vacuum $s=1 / 2 \mathrm{gt} 2$. We shall never experience vacuum in reality on Earth; in spite of this, the formula is used for calculation of the distance an object covers while falling down. It could be thus said that under a wide scope of circumstances, objects falling in real atmosphere behave in the same way as if they were flying in vacuum.

The physical formula of free fall is accepted since it is functional, not because we live in approximate vacuum. Should we drop a feather, the distance it travels in a period of time shall by no means be similar to the distance calculated by the formula of free fall in vacuum. Then it is possible for us to say that a feather brings circumstances so different to the free fall formula, that the formula cannot be used. This, however, must be marked off from a very different statement: that theory is not functional because its assumptions are wrong.

"The relevant relation runs the other way: the assumptions are falls for a feather because the theory does not work. This point needs emphasis, because the entirely valid use of 'assumptions' in specifying the circumstances for which a theory holds is frequently, and erroneously, interpreted to mean that the assumptions can be used to determine the circumstances for which a theory holds, and has, in this way, been as important source of the belief that a theory can be tested by its assumptions" (Friedman 1953: 19)

Friedman mentions yet another theoretical example, saying that leaves on a tree grow in such way, as if every single one of them was trying to maximalize the amount of sunshine it receives, as if knowing the laws of amount of sunshine etc. The hypothesis does not say that leaves do such things; it only says that their density is the same as if they did them. The fact that we do accept the alternative hypothesis of passive adjustment is given by it being more general, not because its assumptions are more real.

"It is only a short step from these examples to the economic hypothesis that under a wide range of circumstances individual firms act as if they were seeking rationally to maximize their expected returns and had full knowledge of the data needed to succeed in this attempt; as if, that is, they knew the relevant cost and demand functions, calculated marginal cost and marginal revenue from all actions open to them, and 
pushed each line of action to the point at which the relevant marginal cost and marginal revenue were equal" (Friedman 1953: 21-22).

\subsection{Other Methodological Writings}

Besides "The Methodology of Positive Economics", Friedman wrote other methodological works, too, among which the article "Lange on Price Flexibility and Employment. A Methodological Criticism" (Friedman 1946) is included. Its author argues against the book of Oskar Lange, the Polish Marxist (1944), reproving Lange for simplification, speculating and use of classifications which lack any empirical counterpart whatsoever.

"The basic sources of the defects in Lange's theoretical analysis are the emphasis on formal structure, the attempt to generalize without first specifying in detail the facts to be generalized, and the failure to recognize that the ultimate test of the validity of a theory is not conformity to the canons of formal logic but the ability to deduce facts that have not yet been observed, that are capable of being contradicted by observation, and that subsequent observation does not contradict" (Friedman 1953: 300).

A similar critical reflection goes to A. P. Lerner (1947). Young Friedman reproves Lerner the fact that his book is a formal analysis of optimum conditions and neglects institutional problems, polemizing with his view that the maximum satisfaction in a society can be achieved by total egalitarianism. Friedman points out that incentives to work and entrepreneurship would fade down in a 'controlled economy' with absolute redistribution. In addition to that, he does not like his Keynesian approach to public finances, and refers to three time lags: recognitive, realisational and implementational.

"Pareto emphasised fifty years ago that equilibrium of source allocation in a society based on private ownership, where there is perfect competition, would be identical with allocation pursued by a socialist state attempting to reach an optimum, and that - on the formal level - a totalitarian arrangement may reach the same source allocation as the free market system. Taylor, Lange, Lerner and other have recently outlined a form of organisation of a socialist society..., in which individual productive unit would 'act' as if in competitive environment and would achieve the same result like the market economy... None of these arrangements will, of course, work perfectly well in practice. The most we can expect from them is a reasonable approximation to the economic optimum“ (Friedman 1953: 317).

Friedman kept a rather critical distance from the Austrian school in her Misesian and Hayekian form. According to him, the fundamental problem of the Misesian methodology, which "does not provide any space for empirical evidence and is widely introspective," dwells it the fact that "it leads to approach of human intolerance. Anyone sharing this methodological approach is, or is becoming an intolerant human being“" (quoted in Hammond 1990: 167).

\section{Conclusion}

Milton Friedman became the most influential economist of the second half of the 20th century. Friedman himself considered the theory of consumer function which rebutted the Keynesian conception of consumption to be the greatest theoretical innovation. At the same time, he laid the foundations of monetarism, resurrected quantity theory of 
money, introduced a new conception of the Phillips curve and explored real effects of stabilisation policies.

Friedman's methodology is sometimes understood as one preferring theories and musing to collecting data and facts. However, Friedman's respect to Mitchell, the Institutionalist, proves that he did not consider abstract theory to be any icon, and did not deem data collection as a futile and useless thing. Friedman criticised not only institutionalist objections against Marshallian economics, but the rigid formalism of Walrassian theory.

Friedman seems to be a kind of a 'compromise' to the imperishable dream of economists to bring into accord theoretical impeccability and empirical relevance. In spite of all its imperfections, Friedman's instrumentalism has become the mainstream in economic methodology. The emphasis on testing consequences of theories is typical of most of contemporary economic theory, and is the basis of econometrics. Instrumentalism is still very popular, for it is a clear, transparent and understandable justification of standard economic theory.

\section{References}

BUTTLER, E. (1985). Milton Friedman. His Economic Thought, Aldershot, Gower Publishing Company Limited.

EBENSTEIN, L. (1997). Milton Friedman. A biography. New York, Palgrave Macmillan

FRAZER, W. (1997). The Friedman System. Economic Analysis of Time Series. London, Praeger Publishers.

FRIEDMAN, M., KUZNETS, S. (1945). Income From Independent Professional Practice. New York, National Bureau of Economic Research.

FRIEDMAN, M. (1946). Lange on Price Flexibility and Employment. A Methodological Criticism. American Economic Review 36, pp. 613-631. In: Friedman (1953), pp. 277-300.

FRIEDMAN, M. (1948). A Monetary and Fiscal Framework for Economic Stability. American Economic Review 38, pp. 245-264.

FRIEDMAN, M. (1949). The Marshallian Demand Curve. Journal of Political Economy 57, pp. 463-495. In: Friedman (1953), pp. 47-99.

FRIEDMAN, M. (1950). Wesley C. Mitchell as an Economic Theorist. Journal of Political Economy, pp. 465-493.

FRIEDMAN, M. (1951). The Effects of a Full-Employment Policy on Economic Stability: A Formal Analysis. Économie appliquée 4, pp. 441-456. In: Friedman (1953), pp. 117-132.

FRIEDMAN, M. (1952). The "Welfare" Effects of an Income Tax and an Excise Tax. Journal of Political Economy 55, pp. 25-33. In: Friedman (1953), pp. 100-116.

FRIEDMAN, M. (1953). Essays in Positive Economics: Chicago. London, The 
University of Chicago Press.

FRIEDMAN, M. (1953a). The Case for Flexible Exchange Rates. In: Friedman (1953), pp. 157-203.

FRIEDMAN, M. (ed.) (1956). Studies in the Quantity Theory of Money. Chicago, University of Chicago Press.

FRIEDMAN, M. (1956b). The Quantity Theory of Money - A Restatement. In: Friedman, M. (ed.). Studies in the Quantity Theory of Money. Chicago, University of Chicago Press, pp. 3-21.

FRIEDMAN, M. (1957). A Theory of the Consumption Function. Princeton, Princeton University Press.

FRIEDMAN, M. (1959). A Program for Monetary Stability. New York, Fordham University Press.

FRIEDMAN, M. (1962). Capitalism and Freedom. Chicago. London, University of Chicago Press.

FRIEDMAN, M., SCHWARTZ, A. (1963). A Monetary History of the United States, 1897-1960. Princeton, Princeton University Press.

FRIEDMAN, M. (1964). Monetary Studies of the National Bureau: The National Bureau Enters Its $45^{\text {th }}$ Year, $44^{\text {th }}$ Annual Report, pp. 7-25. In: Friedman, M. (ed.). The Optimum Quantity of Money and Other Essays. Chicago, Aldine 1969, pp. 261-284.

FRIEDMAN, M. (1968). The Role of Monetary Policy. American Economic Review 58, pp. 1-17.

FRIEDMAN, M., HELLER, W. (1969). Monetary vs. Fiscal Policy. A Dialogue. New York, Norton \& Company.

FRIEDMAN, M. (1970a). Comment on Tobin. Quarterly Journal of Economics 84, pp. 318-327.

FRIEDMAN, M. (1970b). The Social Responsibility of Business Is to Increase Its Profits. New York Times Magazine 13 September 1970.

FRIEDMAN, M. (1976). Price Theory. Chicago, Aldine Publishing.

FRIEDMAN, M., FRIEDMAN, R. (1981). Free to choose. A personal statement. London, Secker \& Warburg.

FRIEDMAN, M., SCHWARTZ, A. J. (1982). Monetary Trends in the United States and the United Kingdom: Their Relation to Income, Prices and Interest Rates, 1867-1975. Chicago - London, University of Chicago Press.

FRIEDMAN, M. (1982b). Milton Friedman and Thatcher's Monetarist Experience. Journal of Economic Issues 16, no. 2, pp. 525-533.

FRIEDMAN, M., FRIEDMAN, R. (1983). The Tyranny of the Status Quo. Harmondsworth, Pengiun Books.

FRIEDMAN, M. (1999). Two Lucky People. Memoirs. Chicago, University of Chicago 
Press.

GOODWIN, T. H., SWEENEY, R. (1993). International Evidence on Friedman's Theory of the Business Cycle. Economic Inquiry 31, pp. 178-193. DOI: 10.1111/j.14657295.1993.tb00875.x

HAMMOND, J. D. (1999). Labels and Substance: Friedman's Restatement of the Quantity Theory. History of Political Economy 31, no. 3, pp. 449-471.

HAMMOND, J. D. (1990). McCloskey's Modernism and Friedman's Methodology: A Case Study With New Evidence. Review of Social Economy 48 (1990), no. 2, pp. 158171. DOI:10.1080/00346769000000014

CHAO, H.-K. (2003): Milton Friedman and the Emergence of the Permanent Income Hypothesis. History of Political Economy 35, pp. 77-104.

JOHNSON, H. G. (1971). The Keynesian Revolution and the Monetarist CounterRevolution. American Economic Review 61, no. 2, pp. 1-14.

LANGE, O. (1944). Price Flexibility and Employment. Bloomington, Ind., Principia Press.

LEESON, R. (2000). Patinkin, Johnson, and the Shadow of Friedman. History of Political Economy 32, no. 4, pp. 733-763.

LERNER, A. P. (1947). Lerner on the Economics of Control. Journal of Political Economy 55, pp. 405-416.

PATINKIN, D. (1969). The Chicago Tradition, the Quantity Theory, and Friedman. Journal of Money, Credit and Banking 1, no. 1, pp. 46-70.

PATINKIN, D. (1981). Essays on and in the Chicago Tradition. Durham, N. C., Duke University Press.

ROBINSON, M. (1999). An Interview with Milton Friedman and Rose Friedman. The American Enterprise. January/February 10, no. 1, p. 18.

SCHWARZ, J. (1999). Milton Friedman. In: Holman, R. a kol. Dějiny ekonomického myšlení. Prague, C. H. Beck, pp. 429-440.

SOJKA, M. (1996). Milton Friedman. Prague, Epocha.

TAVLAS, G. S. (1997). Chicago, Harvard, and the Doctrinal Foundations of Monetary Economics. Journal of Political Economy 105, no. 1, pp. 153-177.

TEIRA, D. (2007). Milton Friedman, the Statistical Methodologist. History of Political Economy 39, pp. 511-527.

THORNTON, J. (1995). Friedman's Money Supply Volatility Hypothesis: Some International Evidence. Journal of Money, Credit, and Banking 27, no. 1, pp. 288-292.

TOBIN, J. (1970). Money and Income: Post Hoc Ergo Propter Hoc? Quarterly Journal of Economics 84, pp. 328-329. 